\title{
Thalassospira xiamenensis sp. nov. and Thalassospira profundimaris sp. nov.
}

\author{
Correspondence \\ Zongze Shao \\ shaozz@163.com
}

\author{
Chenli Liu, Yehui Wu, Li Li, Yingfei Ma and Zongze Shao \\ Key Laboratory of Marine Biogenetic Resources, Third Institute of Oceanography, State \\ Oceanic Administration, PR China
}

\begin{abstract}
Two bacterial strains, $M-5^{\top}$ and $\mathrm{WP} 0211^{\top}$, were isolated from the surface water of a waste-oil pool in a coastal dock and from a deep-sea sediment sample from the West Pacific Ocean, respectively. Analysis of $16 \mathrm{~S}$ rRNA gene sequences indicated that both strains belonged to the class Alphaproteobacteria and were closely related to Thalassospira lucentensis (96.1 and $96.2 \%$, gene sequence similarity, respectively). Based on the results of physiological and biochemical tests, as well as DNA-DNA hybridization experiments, it is suggested that these isolates represent two novel species of the genus Thalassospira. Various traits allow both novel strains to be differentiated from Thalassospira lucentensis, including oxygen requirement, nitrate reduction and denitrification abilities and major fatty acid profiles, as well as their ability to utilize six different carbon sources. Furthermore, the novel strains may be readily distinguished from each other by differences in their motility, flagellation, growth at $4{ }^{\circ} \mathrm{C}$ and $40^{\circ} \mathrm{C}$, their ability to hydrolyse Tween 40 and Tween 80, their utilization of 19 different carbon sources and by quantitative differences in their fatty acid contents. It is proposed that the isolates represent two novel species for which the names Thalassospira xiamenensis sp. nov. (type strain, $M-5^{\top}=\mathrm{DSM} 17429^{\top}=$ CGMCC $1.3998^{\top}$ ) and Thalassospira profundimaris sp. nov. (type strain, WP0211 ${ }^{\top}=\mathrm{DSM} 17430^{\top}=\mathrm{CGMCC} 1.3997^{\top}$ ) are proposed.
\end{abstract}

In a recent study on petroleum-degrading micro-organisms, we reported the isolation and preliminary characterization of several novel bacterial strains from a number of marine habitats (Liu \& Shao, 2005b). Amongst these isolates, strains $\mathrm{M}-5^{\mathrm{T}}$ and $\mathrm{WP} 0211^{\mathrm{T}}$ had similar colony morphologies and shared a high level of $16 \mathrm{~S}$ rRNA gene sequence similarity $(98.5 \%)$. In this study, we present the polyphasic characterization of strains $\mathrm{M}-5^{\mathrm{T}}$ and $\mathrm{WP} 0211^{\mathrm{T}}$.

Strain $M-5^{\mathrm{T}}$ was isolated from the surface water of a wasteoil pool at the oil storage dock in the city of Xiamen, Fujian Province, China, in December 2002. This seawater-based waste-oil pool had suffered long-term pollution with crude oil. Strain WP0211 ${ }^{\mathrm{T}}$ was retrieved from a deep-sea sediment sample, which was collected by a multi-core sampler from the West Pacific (region 973, station WP02-3; $147^{\circ} 58^{\prime} 55^{\prime \prime} \mathrm{E}$ $12^{\circ} 59^{\prime} 54^{\prime \prime} \mathrm{N}$; water depth $4480 \mathrm{~m}$ ), during cruise DY105-13

The GenBank/EMBL/DDBJ accession numbers for the 16S rRNA gene sequences of strains $M-5^{\top}$ and $W P 0211^{\top}$ are $A Y 189753$ and AY186195, respectively.

Transmission electron micrographs of cells of strains $M-5^{\top}$ and WPO2 $11^{\top}$ and dendrograms showing the phylogenetic positions of the two strains based on 16S rRNA gene sequences are available as supplementary figures in IJSEM Online. Tables detailing the DNA-DNA relatedness values and the cellular fatty acid contents of Thalassospira species are also available. of the vessel HAIYANG Number 4 in 2002. The sediment samples were loaded into sterile falcon tubes aboard the ship and were stored at $-20{ }^{\circ} \mathrm{C}$ until subsequent analysis on land.

Bacteria were enriched by culturing in artificial seawater medium (ASM; Liu \& Shao, 2005a), supplemented with $10 \mathrm{~g}$ diesel fuel $1^{-1}$ (strain $\mathrm{M}-5^{\mathrm{T}}$ ) or $5 \mathrm{~g}$ pyrene $\mathrm{l}^{-1}$ (strain $\mathrm{WP} 0211^{\mathrm{T}}$ ) as the sole carbon source. HLB medium (modified from Luria-Bertani medium by increasing the $\mathrm{NaCl}$ concentration to $30 \mathrm{~g} \mathrm{l}^{-1}$; Liu \& Shao, 2005a) was used for routine cultivation of the isolates and for most of the phenotypic tests. All cultures were incubated at $28^{\circ} \mathrm{C}$ with rotation at 200 r.p.m. unless noted otherwise. As was previously found for Thalassospira lucentensis $\mathrm{QMT}^{\mathrm{T}}$ (López-López et al., 2002), both novel strains formed very small colonies in the oligotrophic medium, but showed fairly good growth in the HLB media.

Genomic DNA was prepared according to the method of Ausubel et al. (1995) and the 16S rRNA gene was amplified by PCR using primers that have been described previously (Liu \& Shao, 2005a). Sequence data were manually aligned with nucleotide sequences obtained from GenBank using DNAMAN (version 5.1; Lynnon Biosoft). Phylogenetic dendrograms of 16S rRNA gene sequences were constructed using three different algorithms: the neighbour-joining method (Saitou \& Nei, 1987) using DNAMAN and the 
maximum-likelihood (Felsenstein \& Churchill, 1996) and the maximum-parsimony (Fitch, 1971) methods using the PHYLIP software package (version 3.6a2.1; Felsenstein, 2004). Bootstrap analysis was used to evaluate the tree topology of the data obtained from the three algorithms based on 1000 resamplings. Regions of 1439 and 1457 nucleotides were obtained of the 16S rRNA gene for strains $\mathrm{M}-5^{\mathrm{T}}$ and WP0211 ${ }^{\mathrm{T}}$, respectively. The sequences of strains $\mathrm{M}-5^{\mathrm{T}}$ and $\mathrm{WP} 0211^{\mathrm{T}}$ were highly similar $(98.5 \%$ similarity) and shared the highest levels of homology with T. lucentensis $\mathrm{QMT}^{\mathrm{T}}$ (96.1\% and $96.2 \%$, respectively). The next highest similarities were to Aquaspirillum itersonii subsp. nipponicum DSM $11590^{\mathrm{T}}(90.1 \%$ and $90.2 \%$, respectively), Terasakiella pusilla IFO $13613^{\mathrm{T}}(89.7 \%$ and $89.9 \%$, respectively) and Aquaspirillum peregrinum subsp. integrum DSM $11589^{\mathrm{T}}(89.0 \%$ and $89.0 \%$, respectively). The $16 \mathrm{~S}$ rRNA gene sequences shared lower levels of similarity $(<90.0 \%)$ with all recognized species of the Alphaproteobacteria. In all the phylogenetic trees, the clade containing strains $\mathrm{M}-5^{\mathrm{T}}$, WP0211 ${ }^{\mathrm{T}}$ and T. lucentensis QMT2 $^{\mathrm{T}}$ had $100 \%$ bootstrap support (a neighbour-joining tree is shown in Supplementary Fig. S1 in IJSEM Online).

The morphology of cells from 2-day-old cultures of the novel strains grown on HLB agar was studied using an Olympus inverted microscope and by electron microscopy. Cells of both strains were Gram-negative, had a curved-rod shape and varied from 0.8 to $2.3 \mu \mathrm{m}$ in length and from 0.3 to $0.8 \mu \mathrm{m}$ in width. Strain $\mathrm{M}-5^{\mathrm{T}}$ was motile by means of a single polar flagellum. Conversely, strain WP0211 ${ }^{\mathrm{T}}$ was nonmotile and no flagellae were observed (see Supplementary Fig. S2 in IJSEM Online). The optimal growth temperature was determined over the temperature range $4-55^{\circ} \mathrm{C}$. Sodium requirement was examined at $0,0.5,1,5,7,10$, 15 and $20 \% \mathrm{NaCl}(\mathrm{w} / \mathrm{v})$. The following physiological and biochemical properties were examined according to standard methods: glucose fermentation, denitrification activities, catalase and oxidase activities, gelatin liquefaction activity, the ability to hydrolyse agar, gelatin, starch, Tweens 40 and 80 and arginine dihydrolase activities.

We also investigated the ability of the novel strains to use various organic substrates as sole carbon sources at a concentration of $0.1 \%(\mathrm{w} / \mathrm{v})$ in $5 \mathrm{ml}$ ASM medium. The strains were also characterized using Biolog GN plates as described by Ivanova et al. (1998). Antibiotic activities were assessed as described by Kobayashi et al. (2003). These results are given in the species description.

Cellular fatty acids were analysed by the identification service laboratories of the DSMZ (Deutsche Sammlung von Mikroorganismen und Zellkulturen, Braunschweig, Germany). The fatty acid profiles of both strains are shown in Supplementary Table S1 in IJSEM Online. The predominant fatty acids in both novel isolates were $\mathrm{C}_{18: 1} \omega 7 c, \mathrm{C}_{16: 0}$ and $\mathrm{C}_{18: 0}$ which accounted for $>65 \%$ of the total fatty acids. In T. lucentensis $\mathrm{QMT} 2^{\mathrm{T}}$, the principal fatty acid components were $\mathrm{C}_{18: 1} \omega 7 c, \mathrm{C}_{16: 1} \omega 7 c$ and $\mathrm{C}_{16: 0}$. Similar fatty acid components $\left(\mathrm{C}_{18: 1} \omega 7 c, \mathrm{C}_{16: 0}\right.$ and $\left.\mathrm{C}_{18: 0}\right)$ predominate in some species of the genus Rhodospirillum, such as $R$. salexigens, $R$. salinarum and $R$. sodomense. In some other Rhodospirillum species, such as $R$. rubrum, $R$. photometricum, $R$. fulvum and $R$. molischianum, the main components are $\mathrm{C}_{18: 1} \omega 7 c, \mathrm{C}_{16: 1} \omega 7 c$ and $\mathrm{C}_{16: 0}$ (Imhoff, 1986, 1998; Imhoff \& Bias-Imhoff, 1995). Consequently, no definitive conclusions could be drawn from the major fatty acid profiles of the two novel isolates. There were no significant differences in the minor fatty acid content of strains $\mathrm{M}-5^{\mathrm{T}}, \mathrm{WP} 0211^{\mathrm{T}}$ and T. lucentensis $\mathrm{QMT} 2^{\mathrm{T}}$. Notably, in all of these three strains, the fatty acids $\mathrm{C}_{17: 0}$ cyclo and $\mathrm{C}_{19: 0}$ cyclo were detected in significant amounts, which may be a characteristic chemotaxonomic marker for the genus Thalassospira. These two components were more abundant in strain WP0211 ${ }^{\mathrm{T}}$ (accounting for 5.69 and $5.97 \%$, respectively) than in $\mathrm{M}-5^{\mathrm{T}}$ (1.37 and $\left.1.16 \%\right)$ or $T$. lucentensis $\mathrm{QMT}^{\mathrm{T}}$ (4.77 and $1.86 \%$ ).

The $\mathrm{G}+\mathrm{C}$ content of the genomic DNA of the two novel strains was determined by HPLC after digestion with P1 nuclease (Tamaoka \& Komagata, 1984; Mesbah \& Whitman, 1989). The DNA G $+\mathrm{C}$ contents of strains M$5^{\mathrm{T}}$ and $\mathrm{WP} 0211^{\mathrm{T}}$ were determined to be $52.6 \mathrm{~mol} \%$ and $47.0 \mathrm{~mol} \%$, respectively (with the same experimental standard deviation of $0.09 \%$ ).

DNA-DNA hybridization experiments were performed with genomic DNA from strains $\mathrm{M}-5^{\mathrm{T}}$, WP0211 ${ }^{\mathrm{T}}$ and $T$. lucentensis $\mathrm{QMT}^{\mathrm{T}}$ using a previously described method (Liu \& Shao, 2005a). Genomic DNA from Escherichia coli DH5 $\alpha$ was used as an outgroup sample. The results are shown in Supplementary Table S2 in IJSEM Online. Each value reported is the mean from at least two independent hybridization experiments. Results indicated that the two novel isolates shared high levels of DNA-DNA relatedness $(62-63 \%)$. Notably, both strains had very low levels of DNA-DNA relatedness with E. coli DH5 $\alpha \quad(<5 \%)$. However, strains $\mathrm{M}-5^{\mathrm{T}}$ and $\mathrm{WP} 0211^{\mathrm{T}}$ exhibited relatively low levels of hybridization with $T$. lucentensis $\mathrm{QMT}^{\mathrm{T}}$ (21-23\% and $26 \%$, respectively). This suggested that the new isolates could be classified as novel species of the genus Thalassospira, according to the criteria for the delineation of bacterial species (Wayne et al., 1987).

On the basis of their phenotypic and chemotaxonomic characteristics, their phylogeny based on 16S rRNA gene sequence analysis and their genomic DNA-DNA relatedness, the two new isolates may be categorized as novel members of the genus Thalassospira. We initially considered the possibility that the two strains should be classified as a single species, based on their high levels of 16S rRNA gene sequence similarity $(98.5 \%)$. However, their level of DNADNA relatedness $(62-63 \%)$ falls on the boundary that delineates species (Wayne et al., 1987). Also, the difference in the DNA $\mathrm{G}+\mathrm{C}$ content between strains $\mathrm{M}-5^{\mathrm{T}}$ and WP02 $11^{\mathrm{T}}$ was more than $5 \mathrm{~mol} \%$, which is above the levels that indicate heterogeneity within a species (Goodfellow et al., 1997; Rossello-Mora \& Amann, 2001). Perhaps more significantly, strains $\mathrm{M}-5^{\mathrm{T}}$ and $\mathrm{WP} 0211^{\mathrm{T}}$ have a number of 
distinct physiological and chemotaxonomic properties that allow them to be distinguished from each other, i.e. motility, flagellation, growth at 4 and $40^{\circ} \mathrm{C}$, hydrolysis of Tweens 40 and 80 , utilization of 19 different carbon sources (Table 1) and quantitative differences in their fatty acid content (see Supplementary Table S1). Therefore, we propose that these two new strains be designated as representatives of two novel species: Thalassospira xiamenensis sp. nov. for strain $\mathrm{M}-5^{\mathrm{T}}$ and Thalassospira profundimaris sp. nov. for strain $\mathrm{WP} 0211^{\mathrm{T}}$.

It should be noted that although strains M-5 ${ }^{\mathrm{T}}$ and WP0211 were isolated separately from bacterial consortia that used hydrocarbons as their sole carbon source, neither strain could degrade any of the hydrocarbons tested in this study. However, the analysis of $16 \mathrm{~S}$ rRNA gene sequences obtained from various samples from marine environments has revealed that these two novel species and their close relatives were frequently detected in petrol-oil-degrading consortia (unpublished data). This indicates they may play some role in the degradation of petroleum hydrocarbons. However, it is presently difficult to speculate upon their exact biological role and this area requires further detailed study.

\section{Emended description of the genus Thalassospira López-López et al. 2002}

Cells are non-motile and non-flagellated or motile by a single polar flagellum. Some species can grow under anaerobic conditions by reducing nitrate. Species are halophilic; require $\mathrm{Na}^{+}$ions for growth and are able to grow in the presence of up to $10 \% \mathrm{NaCl}$. No requirement for organic growth factors. Carbohydrates are used as the sole carbon source and both nitrate and ammonium are used as sole nitrogen sources. The major hydroxylated fatty acid is $\mathrm{C}_{16: 0} 3-\mathrm{OH}$. The $\mathrm{G}+\mathrm{C}$ content of the genomic DNA ranges from 47 to $54.7 \mathrm{~mol} \%$. On the basis of $16 \mathrm{~S}$ rRNA gene sequence-based phylogenetic analyses, the genus belongs to the Alphaproteobacteria.

\section{Description of Thalassospira xiamenensis sp. nov.}

Thalassospira xiamenensis (xi.a.me.nen'sis. N.L. fem. adj. xiamenensis pertaining to Xiamen, the city where the organism was first isolated).

Cells are $0.8-2.3 \mu \mathrm{m}$ long and $0.3-0.8 \mu \mathrm{m}$ wide, non-sporeforming, Gram-negative curved rods that are motile by means of one polar flagellum. Colonies on HLB agar are circular, convex, glistening, viscid, translucent and yellowish. Mesophilic; growth temperature ranges from 4 to $40^{\circ} \mathrm{C}$ (optimum $22^{\circ} \mathrm{C}$ ). $\mathrm{NaCl}$ is required for growth, cells grow at $0.5-10 \% \mathrm{NaCl}$ (optimum at 2-4\%). Produces acid from Dglucose under aerobic conditions. Positive for catalase and oxidase activities, but negative for arginine dihydrolase, amylase and gelatinase activity. Cannot hydrolyse Tween 40, Tween 80 or agar. Nitrate is reduced to nitrite. Facultatively anaerobic; can grow in anaerobic conditions by reducing nitrate. Sensitive to the following antibiotics $(10 \mu \mathrm{g}$ per $6 \mathrm{~mm}$ disc): chloramphenicol, norfloxacin, furazolidone, co-trimoxazole, ofloxacin, midecamycin, ceftriaxone, polymyxin B, doxycycline, tetracycline, neomycin, kanamycin, gentamicin, amikacin, erythromycin, minocycline, carbenicillin, cefalexin, cephradine, ciprofloxacin and cefuroxime, but resistant to: cefoperazone, clindamycin, vancomycin, ceftazidime, cefazolin, penicillin, oxacillin, ampicillin and piperacillin. Among the 95 carbon sources in the Biolog system, the following are utilized: $N$-acetyl-D-glucosamine, L-arabinose, D-arabitol, D-cellobiose, D-fructose, D-galactose, $\alpha$-D-glucose, myo-inositol, maltose, D-mannitol, Dmannose, sucrose, D-trehalose, turanose, monomethyl succinate, methyl pyruvate, cis-aconitic acid, formic acid, D-gluconic acid, $\alpha$-hydroxybutyric acid, $\beta$-hydroxybutyric acid, $\gamma$-hydroxybutyric acid, $\alpha$-ketoglutaric acid, DL-lactic acid, quinic acid, malonic acid, propionic acid, succinic acid, bromosuccinic acid, L-alaninamide, D-alanine, Lalanine, L-alanyl glycine, L-asparagine, L-histidine, hydroxy-L-proline, L-ornithine, L-glutamic acid, glycyl Lglutamic acid, L-proline, L-serine, L-pyroglutamic acid, urocanic acid, thymidine and glycerol. Principal fatty acids are $\mathrm{C}_{18: 1} \omega 7 c, \mathrm{C}_{16: 0}, \mathrm{C}_{18: 0}, \mathrm{C}_{16: 1} \omega 7 c$ and $\mathrm{C}_{14: 0}$, with minor amounts of $\mathrm{C}_{13: 1}, \mathrm{C}_{16: 0} 3-\mathrm{OH}, \mathrm{C}_{17: 0}$ cyclo and $\mathrm{C}_{19: 0}$ cyclo and small amounts of 11 methyl $\mathrm{C}_{18: 1} \omega 7 c \mathrm{c} \mathrm{G}+\mathrm{C}$ content of the genomic DNA is $52.6 \mathrm{~mol} \%$. Table 1 shows characteristics used to distinguish strain $\mathrm{M}-5^{\mathrm{T}}$ from other members of the genus Thalassospira.

The type strain, $\mathrm{M}-5^{\mathrm{T}}\left(=\mathrm{DSM} 17429^{\mathrm{T}}=\right.$ CGMCC $\left.1.3998^{\mathrm{T}}\right)$, was isolated from surface water collected from a waste-oil pool at an oil storage dock in the city of Xiamen on the Eastern coast of China.

\section{Description of Thalassospira profundimaris sp. nov.}

Thalassospira profundimaris (pro.fun.di.ma'ris. L. adj. profundus deep; L. gen. n. maris from/of the sea; N.L. gen. n. profundimaris from/of the deep-sea, reflecting from where the type strain was isolated).

Cells are Gram-negative curved rods that are $0.8-2.3 \mu \mathrm{m}$ long and $0.3-0.8 \mu \mathrm{m}$ wide. Cells are non-motile, nonflagellated and non-spore-forming. Colonies on HLB agar are circular, convex, glistening, viscid, translucent and opalescent. Mesophilic; grows between 10 and $37^{\circ} \mathrm{C}$ (optimum of $22^{\circ} \mathrm{C}$ ). No growth occurs at 4 or $40^{\circ} \mathrm{C}$. $\mathrm{NaCl}$ is required for growth; cells grow in $2-8 \% \mathrm{NaCl}$ (optimum 3-4\%). Does not produce acid from D-glucose under aerobic conditions. Actively hydrolyses Tween 40 and Tween 80 , but not agar. Catalase- and oxidase-positive, but negative for arginine dihydrolase, amylase and gelatinase activities. Nitrate is reduced to nitrite. Facultatively anaerobic; grows in anaerobic conditions by reducing nitrate. Sensitive to the following antibiotics $(10 \mu \mathrm{g}$ per $6 \mathrm{~mm}$ disc): chloramphenicol, norfloxacin, furazolidone, co-trimoxazole, ofloxacin, midecamycin, ceftriaxone, polymyxin B, doxycycline, tetracycline, neomycin, kanamycin, 


\section{Table 1. Characteristics that differentiate strains $M-5^{\top}, \mathrm{WPO} 211^{\top}$ and $T$. lucentensis $\mathrm{QMT} 2^{\top}$}

Taxa: 1, M-5 ${ }^{\mathrm{T}}$ (data from this study); 2, WP0211 ${ }^{\mathrm{T}}$ (this study); 3, T. lucentensis QMT2 ${ }^{\mathrm{T}}$ (López-López et al., 2002). ND, No data; +, positive reaction or growth; -, no reaction or growth; W, weak reaction. All species are positive in tests for the following characteristics: growth on carbohydrates, catalase activity, oxidase activity, use of nitrate as sole nitrogen source, $\mathrm{Na}^{+}$requirement, utilization of L-arabinose, D-cellobiose, D-fructose, D-mannose, methyl pyruvate, D-gluconic acid, D-glucosaminic acid, $\gamma$-hydroxybutyric acid, DL-lactic acid, propionic acid, succinic acid, L-alanine, L-alanyl glycine, L-glutamic acid and glycerol. All species are negative in tests for the following characteristics: agar hydrolysis, arginine dihydrolase activity, amylase activity, gelatinase activity, growth-factor requirement, utilization of $\alpha$-D-lactose, D-melibiose, D-raffinose and D-sorbitol.

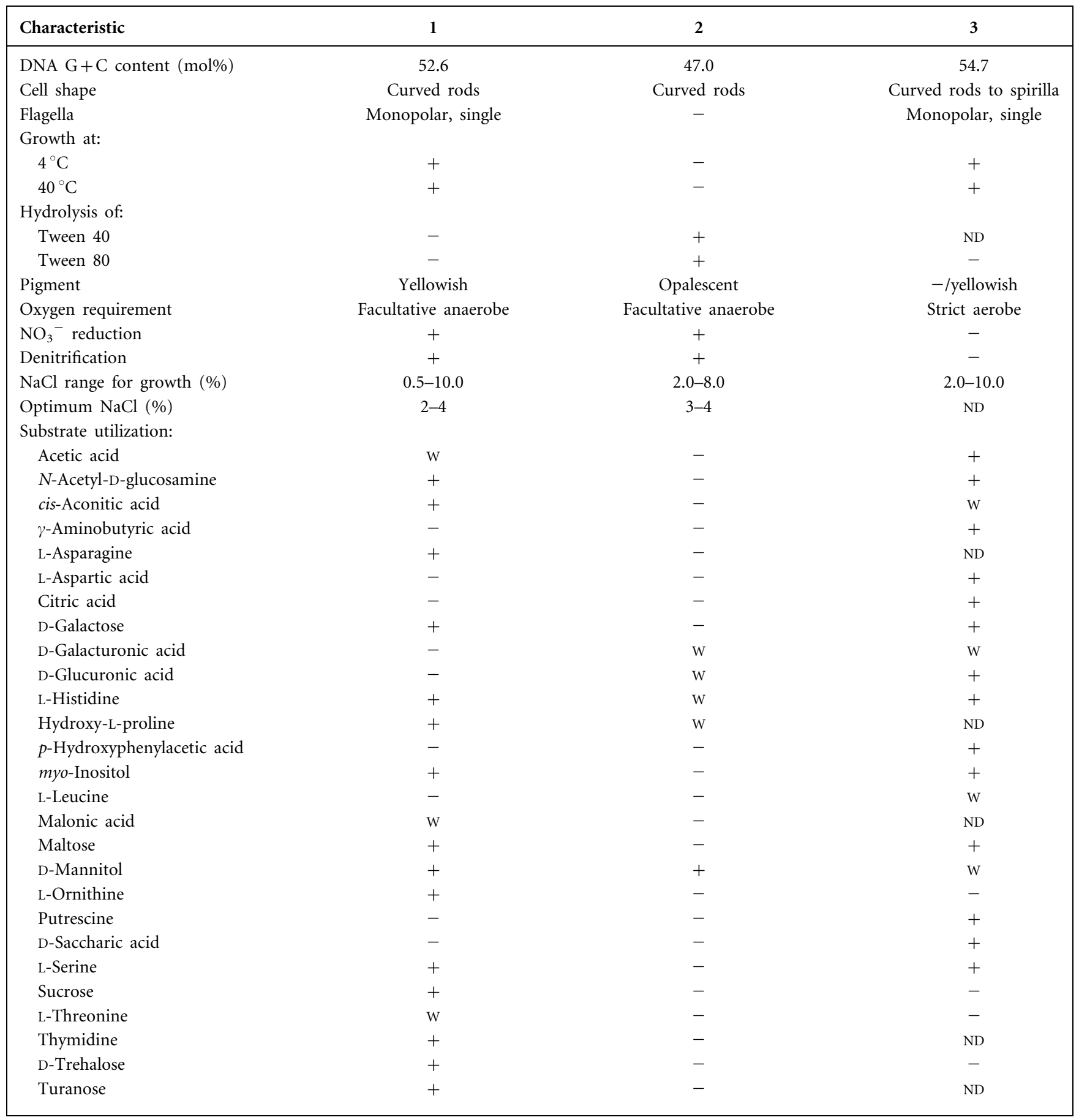


gentamicin, amikacin, erythromycin, minocycline, carbenicillin, cefalexin, ciprofloxacin, cefoperazone, vancomycin, ceftazidime, cefazolin, penicillin, oxacillin, ampicillin and piperacillin. Resistant to the following antibiotics: clindamycin, cefuroxime and cephradine. Among the 95 carbon sources in the Biolog system, the following are utilized: Tween 40, Tween 80, D-arabitol, D-cellobiose, D-fructose, $\alpha$ D-glucose, D-mannitol, D-mannose, monomethyl succinate, methyl pyruvate, formic acid, $\beta$-hydroxybutyric acid, $\gamma$ hydroxybutyric acid, $\alpha$-ketoglutaric acid, DL-lactic acid, quinic acid, propionic acid, succinic acid, D-gluconic acid, L-alanine, L-alanyl glycine, L-glutamic acid, glycyl Lglutamic acid, L-proline, L-pyroglutamic acid and glycerol. Principal fatty acids are $\mathrm{C}_{18: 1} \omega 7 c, \mathrm{C}_{16: 0}, \mathrm{C}_{18: 0}, \mathrm{C}_{19: 0}$ cyclo and $\mathrm{C}_{17: 0}$ cyclo; with minor amounts of $\mathrm{C}_{14: 0}, \mathrm{C}_{16: 1} \omega 7 c$, $\mathrm{C}_{16: 0} 3-\mathrm{OH}$ and $\mathrm{C}_{13: 1}$ and small amounts of 11 methyl $\mathrm{C}_{18: 1} \omega 7 c$. G $+\mathrm{C}$ content of the genomic DNA is $47 \mathrm{~mol} \%$. Table 1 shows characteristics used to distinguish strain WP0211 ${ }^{\mathrm{T}}$ from other members of the genus Thalassospira.

The type strain, WP0211 $\left(=\mathrm{DSM} 17430^{\mathrm{T}}=\mathrm{CGMCC}\right.$ $\left.1.3997^{\mathrm{T}}\right)$, was isolated from a deep-sea sediment from the West Pacific Ocean.

\section{Acknowledgements}

We are grateful to Dr R. Rosselló-Mora for his helpful discussions and comments, Dr Hans Trüper for his help with issues related to bacterial etymology and to Dr Rory Watt for his comments and assistance in preparing the manuscript. This work was financially supported by the COMRA Program (No. DY105-04-02-06), the National Infrastructure of Natural Resources for Science and Technology program (No. 2005DKA21209) and the National Natural Science Foundation of China (40376041).

\section{References}

Ausubel, F. M., Brent, R., Kingston, R. E., Moore, D. D., Seidman, J. G., Smith, J. A. \& Struhl, K. (1995). Short Protocols in Molecular Biology: a Compendium of Methods from Current Protocols in Molecular Biology, 3rd edn. New York: Wiley.

Felsenstein, J. (2004). PHYLIP (phylogeny inference package), version 3.6. Distributed by the author. Department of Genome Sciences, University of Washington, Seattle, USA.

Felsenstein, J. \& Churchill, G. A. (1996). A Hidden Markov Model approach to variation among sites in rate of evolution. Mol Biol Evol 13, 93-104.

Fitch, W. M. (1971). Toward defining the course of evolution: minimum change for a specific tree topology. Syst Zool 20, 406-416.

Goodfellow, M., Manco, G. P. \& Chun, J. (1997). Towards a practical species concept for cultivable bacteria. In Species: the Units of Biodiversity, pp. 25-59. Edited by M. F. Claridge \& H. A. Dawah. London: Chapman \& Hall.
Imhoff, J. F. (1986). Biologie halophiler anoxygener phototropher Eubakterien. Untersuchungen zur Okologie, Taxonomie und Physiologie. Universität Bonn: Habilitationsschrift (in German).

Imhoff, J. F. \& Bias-Imhoff, U. (1995). Lipids, quinones and fatty acids of anoxygenic phototrophic bacteria. In Anoxygenic Photosynthetic Bacteria, pp. 179-205. Edited by R. E. Blankenship, M. T. Madigan \& C. E. Bauer. Dordrecht: Kluwer Academic Publishers.

Imhoff, J. F., Petri, R. \& Suling, J. (1998). Reclassification of species of the spiral-shaped phototrophic purple non-sulfur bacteria of the $\alpha$-Proteobacteria: description of the new genera Phaeospirillum gen. nov., Rhodovibrio gen. nov., Rhodothalassium gen. nov. and Roseospira gen. nov. as well as transfer of Rhodospirillum fulvum to Phaeospirillum fulvum comb. nov., of Rhodospirillum molischianum to Phaeospirillum molischianum comb. nov., of Rhodospirillum salinarum to Rhodovibrio salinarum comb. nov., of Rhodospirillum sodomense to Rhodovibrio sodomensis comb. nov., of Rhodospirillum salexigens to Rhodothalassium salexigens comb. nov. and of Rhodospirillum mediosalinum to Roseospira mediosalina comb. nov. Int J Syst Bacteriol 48, 793-798.

Ivanova, E. P., Kiprianova, E. A., Mikhailov, V. V., Levanova, G. F., Garagulya, A. D., Gorshkova, N. M., Vysotskii, M. V., Nicolau, D. V., Yumoto, N. \& other authors (1998). Phenotypic diversity of Pseudoalteromonas citrea from different marine habitats and emendation of the description. Int J Syst Bacteriol 48, 247-256.

Kobayashi, T., Imada, C., Hiraishi, A., Tsujibo, H., Miyamoto, K., Inamori, Y., Hamada, N. \& Watanabe, E. (2003). Pseudoalteromonas sagamiensis sp. nov., a marine bacterium that produces protease inhibitors. Int J Syst Evol Microbiol 53, 1807-1811.

Liu, C. \& Shao, Z. (2005a). Alcanivorax dieselolei sp. nov., a novel alkane-degrading bacterium isolated from sea water and deep-sea sediment. Int J Syst Evol Microbiol 55, 1181-1186.

Liu, C. \& Shao, Z. (2005b). Isolation and characterization of oildegrading marine microorganisms. Acta Oceanologica Sinica 27, 114-120.

López-López, A., Pujalte, M. J., Benlloch, S., Mata-Roig, M., Rosselló-Mora, R., Garay, E. \& Rodríguez-Valera, F. (2002). Thalassospira lucentensis gen. nov., sp. nov., a new marine member of the $\alpha$-Proteobacteria. Int J Syst Evol Microbiol 52, 1277-1283.

Mesbah, M. \& Whitman, W. B. (1989). Measurement of deoxyguanosine/thymidine ratios in complex mixtures by high-performance liquid chromatography for determination of the mole percentage guanine + cytosine of DNA. J Chromatogr 479, 297-306.

Rossello-Mora, R. \& Amann, R. (2001). The species concept for prokaryotes. FEMS Microbiol Rev 25, 39-67.

Saitou, N. \& Nei, M. (1987). The neighbor-joining method: a new method for reconstructing phylogenetic trees. Mol Biol Evol 4, 406-425.

Tamaoka, J. \& Komagata, K. (1984). Determination of DNA base composition by reversed-phase high-performance liquid chromatography. FEMS Microbiol Lett 25, 125-128.

Wayne, L. G., Brenner, D. J., Colwell, R. R., Grimont, P. A. D. Kandler, O., Krichevsky, M. I., Moore, L. H., Moore, W. E. C., Murray, R. G. E. \& other authors (1987). International Committee on Systematic Bacteriology. Report of the ad hoc committee on reconciliation of approaches to bacterial systematics. Int $J$ Syst Bacteriol 37, 463-464. 